\title{
Targeting Tumor Cell-Platelet Interaction in Breast Cancer Metastasis
}

\author{
Brunhilde Felding-Habermann \\ The Scripps Research Institute, La Jolla, Calif., USA
}

\section{Hematogenous Metastasis}

Metastatic cells often use the bloodstream to colonize distant target organs. To do this, tumor cells must detach from the primary tumor, gain access to blood vessels, and survive and manage the unique conditions in the vasculature. In this environment, tumor cells are confronted with plasma proteins, erythrocytes, leukocytes and platelets. The metastatic cells are further exposed to shear forces that are generated by blood flow and physically oppose cell attachment. It is generally accepted that fairly large numbers of cells from a primary tumor enter the circulation. However, only few will give rise to metastases [1]. To colonize their target organs successfully, tumor cells must attach to vascular endothelial cells or components of the vessel wall. This is mediated by specific adhesive functions of tumor cell receptors, including integrins. In the live host, it is not clear whether tumor cells attach directly to the endothelium. They may require crosslinking plasma protein ligands and support by platelets and/or leukocytes to adhere to the vessel wall in the presence of flow dependent shear forces [2]. Tumor cells that fail to attach are rapidly cleared from the circulation. Metastatic cells that manage to arrest within microvessels of their target organs either extravasate, or start to proliferate at the attachment site [3]. Cells that cannot proliferate within the vasculature undergo rapid apoptosis [4]. Non-proliferating extravasated cells may remain dormant for extended periods of time [5]. Failure to

\begin{tabular}{ll}
\hline KARGER & (c) 2003 S. Karger AG, Basel \\
Fax $+41613061234-8832 / 03 / 0337-0056 \$ 19.50 / 0$ \\
$\begin{array}{l}\text { E-Mail karger@karger.ch } \\
\text { www.karger.com }\end{array}$ & $\begin{array}{l}\text { Accessible online at: } \\
\text { www.karger.com/journals/pht }\end{array}$
\end{tabular}

proliferate within target organs of metastasis is mediated, at least in part, by metastasis suppressor genes [6]. Interestingly, these genes do not affect primary tumor growth [7]. Their mechanism of action and relation to the functionality of adhesion molecules are still unclear [8]. However, integrin supported adhesion of circulating tumor cells, and their interaction with platelets within the vasculature not only represents the first critical step toward target organ colonization, but also contributes to tumor cell survival and proliferation at the secondary site [9] (fig. 1).

\section{Tumor Cell Arrest}

The first critical step in tumor cell anchorage within the vasculature is shear resistant attachment to the endothelium or to components of the vessel wall. Under these conditions, tumor cell integrin $\alpha v \beta 3$ plays a special role, because it uniquely mediates tumor cell arrest under dynamic flow conditions [2]. In flowing blood, $\alpha v \beta 3$ supports tumor cell interaction with adherent platelets and leukocytes. This results in shear resistant tumor cell arrest [10]. To mediate tumor cell binding to platelets, $\alpha v \beta 3$ must be activated, and the interaction requires multivalent plasma protein ligands as crosslinking bridges [10]. In these respects, $\alpha \mathrm{v} \beta 3$ resembles leukocyte integrins of the $\beta 4$ and $\beta 2$ families and platelet integrin $\alpha \mathrm{II} \beta 3$. In breast cancer cells, integrin $\alpha \mathrm{v} \beta 3$ can exist in a constitutively activated or a non-activated

Brunhilde Felding-Habermann, $\mathrm{PhD}$

Assistant Professor

The Scripps Research Institute

MEM 175, 10550 North Torrey Pines Road

La Jolla, CA 92037 (USA)

Tel. +1 858784 2021, Fax +1 858784 2030, E-Mail brunie@scripps.edu 


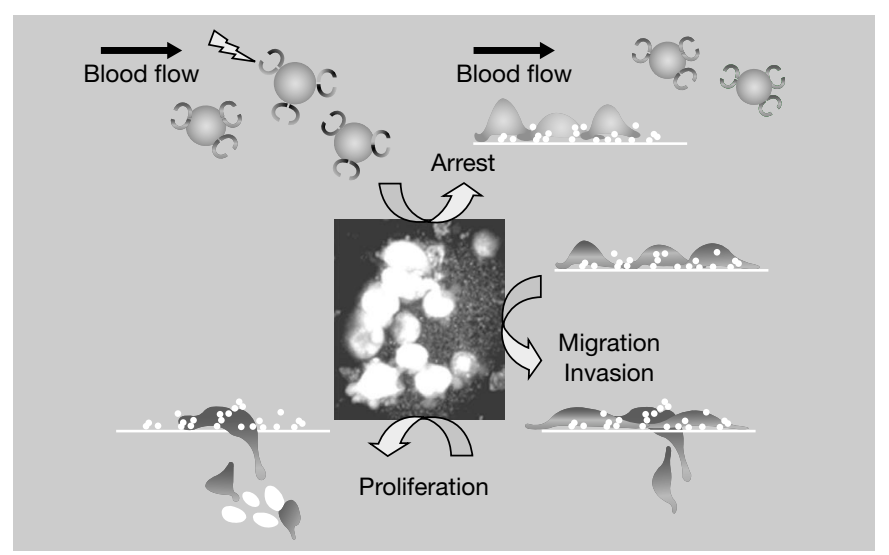

Fig. 1. Interaction between circulating tumor cells and activated platelets may contribute to critical steps in the metastatic cascade. The interaction can promote tumor cell arrest within the vasculature. This is mediated by activated integrin $\alpha \mathrm{v} \beta 3$ expressed on aggressive metastatic breast cancer cells. Cells expressing non-activated $\alpha v \beta 3$ are unable to arrest and metastasize. After tumor cell arrest, platelet interaction may promote tumor cell migration and invasion. Tumor cells with activated integrin $\alpha \mathrm{v} \beta 3$ can convert platelet released proteases, e.g. metalloproteinase MMP-9, into their active formats which promote tumor cell migration and invasive penetration. At the perivascular site, tumor cells may perceive growth signals from platelets and leukocytes that are present in the heteroaggregate which fostered the arrest step.

functional form. Importantly, expression of activated $\alpha \mathrm{v} \beta 3-$ but not that of non-activated $\alpha v \beta 3$ - is associated with a highly aggressive metastatic phenotype [10]. Thus, expression of $\alpha \mathrm{v} \beta 3$ on circulating tumor cells in a constitutively activated form, or in a state that allows rapid activation under blood flow conditions, provides a selective advantage for successful metastasis. This concept is supported by in vivo studies showing that in certain tumor cell types expression of $\alpha v \beta 3$ is required for hematogenous metastasis, and that inhibition of $\alpha \mathrm{v} \beta 3$ function on circulating tumor cells strongly inhibits colonization of target organs $[10,11]$. Transfection of melanoma cells with either $\alpha \mathrm{v} \beta 3$ or platelet receptor $\alpha \operatorname{IIb} \beta 3$ indicated that both receptors mediate tumor cell arrest during blood flow, but only integrin $\alpha v \beta 3$ supported hematogenous metastasis. This is likely due to the fact that $\alpha v \beta 3$ further mediates tumor cell migration and invasion, while $\alpha \operatorname{IIb} \beta 3$ fails to do so [2]. Therefore, expression of an integrin adhesion receptor that supports interaction with platelets during blood flow and further functions, that are critical for post arrest events, promotes a metastatic tumor cell phenotype. In breast cancer cells, these functions are strongly enhanced when the integrin is expressed in a constitutively activated form, as shown for $\alpha v \beta 3$ [10].

Targeting Tumor Cell-Platelet Interaction in Breast Cancer Metastasis

\section{Migration and Invasion}

To analyze post arrest events and specific contributions of activated breast cancer cell integrin $\alpha \mathrm{v} \beta 3$, we compared in vitro generated and in vivo selected variants of a human breast cancer cell model. These variants express either constitutively activated or non-activated $\alpha v \beta 3$. We included a variant that lacks $\alpha v \beta 3$. To test a clinical relevance of activated $\alpha v \beta 3$, we further analyzed primary metastatic cells isolated from blood samples of stage IV breast cancer patients. These primary metastatic cells express a strongly platelet-interactive phenotype, which is mediated by integrin $\alpha v \beta 3$. Based on this criterion and further functional tests, $\alpha v \beta 3$ is constitutively activated on patient derived circulating metastatic breast cancer cells.

We found that metastatic, activated $\alpha v \beta 3$ expressing breast cancer cells produce a soluble factor, which strongly promotes $\alpha v \beta 3$ dependent migration. We identified this factor as metalloproteinase MMP-9 [12]. MMP-9 and several other MMPs are secreted as latent pro-enzymes by tumor cells, host stromal cells, leukocytes and platelets [13-15]. It is still unknown how the latent protease is targeted to the surface on invading cells. However, it is clear that the latent enzyme must bind to the cell surface where it is converted to the active enzyme, which then degrades proteins in the pericellular space [16]. We found that metastatic breast cancer cells, which express activated integrin $\alpha v \beta 3$, convert pro-MMP-9 into enzymatically active MMP-9 [12]. This is true for pro-MMP-9 produced by the tumor cells or when exogenously added. In contrast, poorly metastatic cells, which express non-activated $\alpha v \beta 3$, may produce pro-MMP-9 or receive it from another source, but they are unable to convert the enzyme into active MMP-9. It is only active MMP-9 that promotes $\alpha v \beta 3$ mediated breast cancer cell migration. The enzyme does so by modifying the tumor cell surface and by degrading proteins in the microenvironment of the cell [12].

Other MMPs, such as MMP-2, are known to promote endothelial cell invasion during angiogenesis. MMP-2 can interact with endothelial integrin $\alpha v \beta 3[17,18]$. The integrin is involved in MMP-2 maturation in non-metastatic breast cancer cells [19]. However, neither pro- nor active MMP-2 promoted $\alpha \mathrm{v} \beta 3$ dependent migration in our breast cancer cell model [12]. Importantly, the activation state of tumor cell integrin $\alpha \mathrm{v} \beta 3$, which profoundly affects metastatic activity, had no effect on MMP-2 processing [12]. Thus, our results suggest a new pathway, where activation of breast cancer cell adhesion receptor integrin $\alpha v \beta 3$ triggers activation of metalloproteinase MMP-9 at the tumor cell surface, and thereby initiates a cascade of events that promote breast cancer spreading (fig. 2).

Pathophysiol Haemost Thromb

2003;33(suppl 1):56-58 


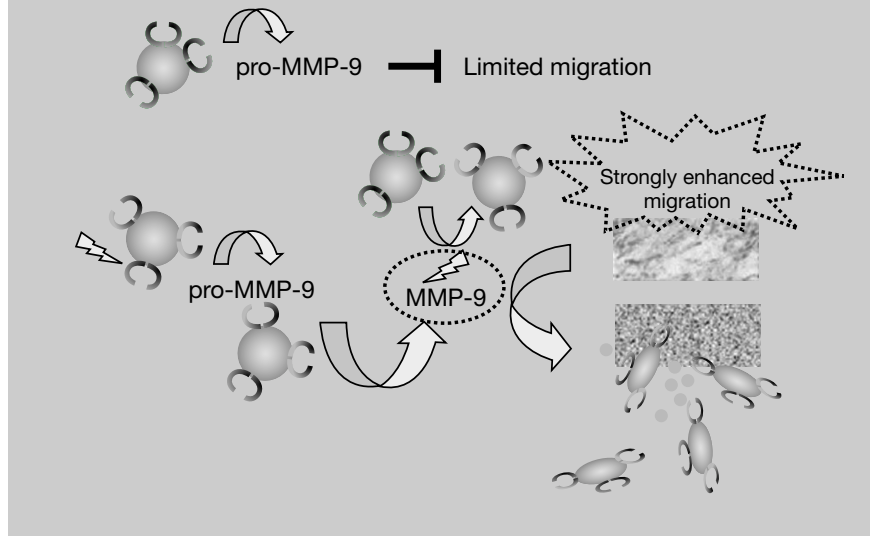

Fig. 2. Functional consequences of the integrin $\alpha v \beta 3 / \mathrm{MMP}-9$ activation pathway. Breast cancer cells expressing constitutively activated integrin $\alpha v \beta 3$ - but not those expressing non-activated $\alpha v \beta 3$ - can convert latent metalloproteinase MMP-9 into enzymatically active MMP-9. Active MMP-9 strongly promotes $\alpha v \beta 3$ mediated breast cancer cell migration by modifying the tumor cell surface, and by degrading matrix and other proteins in the pericellular space.

\section{Survival and Proliferation at the Perivascular Site}

Considering the arrest of circulating tumor cells in the vasculature an initial critical step, and appreciating the interaction between arresting tumor cells and platelets as a mechanism that supports this step, the following concept emerges. A malignant event renders integrin $\alpha v \beta 3$ constitutively activated at the tumor cell surface. The activated integrin supports arrest of circulating tumor cells within the blood stream by promoting tumor cell binding to vascular cells, likely via interaction with activated platelets. In close contact or surrounded by activated platelets, the arrested tumor cells are exposed to a multitude of platelet released factors at a high local concentration. Such factors include integrin ligands, growth factors, and proteases such as MMP-9. In this microenvironment, activated tumor cell integrin $\alpha \mathrm{v} \beta 3$ can support conversion of pro-MMP-9 to active MMP-9. This triggers matrix degradation and strongly promotes tumor cell migration and invasion. During this process, vascular permeability factors are released and allow platelet and leukocyte derived growth factors to permeate into the perivascular space where they support the proliferation of invading metastatic cells (fig. 1).

\section{References}

1 Orr FW, Wang HH: Tumor cell interactions with the microvasculature: A rate-limiting step in metastasis. Surg Oncol Clin N Am 2001;10:357-381.

2 Pilch J, Habermann R, Felding-Habermann B: Unique ability of integrin $\alpha(v) \beta 3$ to support tumor cell arrest under dynamic flow conditions. J Biol Chem 2002;277:21930-21938.

3 Al Mehdi AB, Tozawa K, Fisher AB, Shientag L, Lee A, Muschel RJ: Intravascular origin of metastasis from the proliferation of endotheliumattached tumor cells: A new model for metastasis. Nat Med 2000;6:100-102.

4 Wong CW, Lee A, Shientag L, Yu J, Dong Y, Kao G, Al Mehdi AB, Bernhard EJ, Muschel RJ: Apoptosis: An early event in metastatic inefficiency. Cancer Res 2001;61:333-338.

5 Chambers AF, Naumov GN, Varghese HJ, Nadkarni KV, MacDonald IC, Groom AC: Critical steps in hematogenous metastasis: An overview. Surg Oncol Clin N Am 2001;10:243-255, vii.

6 Welch DR, Steeg PS, Rinker-Schaeffer CW: Molecular biology of breast cancer metastasis. Genetic regulation of human breast carcinoma metastasis. Breast Cancer Res 2000;2:408-416.

7 Shevde LA, Samant RS, Goldberg SF, Sikaneta T, Alessandrini A, Donahue HJ, Mauger DT, Welch DR: Suppression of human melanoma metastasis by the metastasis suppressor gene BRMS1. Exp Cell Res 2002;273:229-239.
8 Samant RS, Seraj MJ, Saunders MM, Sakamaki TS, Shevde LA, Harms JF, Leonard TO, Goldberg SF, Budgeon L, Meehan WJ, Winter CR, Christensen ND, Verderame MF, Donahue HJ, Welch DR: Analysis of mechanisms underlying BRMS1 suppression of metastasis. Clin Exp Metastasis 2000;18:683-693.

9 Abdel-Ghany M, Cheng HC, Elble RC, Pauli BU: Focal adhesion kinase activated by beta 4 integrin ligation to mCLCA1 mediates early metastatic growth. J Biol Chem 2002;277(37):34391-34400.

10 Felding-Habermann B, O'Toole TE, Smith JW, Fransvea E, Ruggeri ZM, Ginsberg MH, Hughes PE, Pampori N, Shattil SJ, Saven A, Mueller BM: Integrin activation controls metastasis in human breast cancer. Proc Natl Acad Sci USA 2001;98:1853-1858.

11 Trikha M, Zhou Z, Timar J, Raso E, Kennel M, Emmell E, Nakada MT: Multiple roles for platelet GPIIb/IIIa and $\alpha v \beta 3$ integrins in tumor growth, angiogenesis, and metastasis. Cancer Res 2002;62:2824-2833.

12 Rolli M, Fransvea E, Pilch J, Saven A, Felding-Habermann B: Activated integrin $\alpha v \beta 3$ cooperates with metalloproteinase MMP-9 in regulating migration of metastatic breast cancer cells. Proc Natl Acad Sci USA 2003, in press.

13 Huang S, Van Arsdall M, Tedjarati S, McCarty M, $\mathrm{Wu} \mathrm{W}$, Langley R, Fidler IJ: Contributions of stromal metalloproteinase- 9 to angiogenesis and growth of human ovarian carcinoma in mice. J Natl Cancer Inst 2002;94:1134-1142.
14 Bergers G, Brekken R, McMahon G, Vu TH, Itoh T, Tamaki K, Tanzawa K, Thorpe P, Itohara S, Werb Z, Hanahan D: Matrix metalloproteinase-9 triggers the angiogenic switch during carcinogenesis. Nat Cell Biol 2000;2:737-744.

15 Coussens LM, Tinkle CL, Hanahan D, Werb Z: MMP-9 supplied by bone marrow-derived cells contributes to skin carcinogenesis. Cell 2000;103: 481-490.

16 Fridman R: Surface association of secreted matrix metalloproteinases. Curr Top Dev Biol 2003;54: 75-100.

17 Brooks PC, Stromblad S, Sanders LC, von Schalscha TL, Aimes RT, Stetler-Stevenson WG, Quigley JP, Cheresh DA: Localization of matrix metalloproteinase MMP-2 to the surface of invasive cells by interaction with integrin $\alpha v \beta 3$. Cell 1996;85:683-693.

18 Brooks PC, Silletti S, von Schalscha TL, Friedlander M, Cheresh DA: Disruption of angiogenesis by PEX, a noncatalytic metalloproteinase fragment with integrin binding activity. Cell, 1998;92:391-400.

19 Deryugina EI, Ratnikov B, Monosov E, Postnova TI, DiScipio R, Smith JW, Strongin AY: MT1MMP initiates activation of pro-MMP-2 and integrin $\alpha v \beta 3$ promotes maturation of MMP- 2 in breast carcinoma cells. Exp Cell Res 2001; 263:209-223 